\title{
CLINICAL, HEMATOLOGICAL, AND SEMINAL ALTERATIONS AND PARASITEMIA OF MALE GOATS EXPERIMENTALLY INFECTED WITH Toxoplasma gondii
}

\section{ALTERAÇÕES CLÍNICAS, HEMATOLÓGICAS, SEMINAIS E PARASITEMIA DE CAPRINOS MACHOS EXPERIMENTALMENTE INFECTADOS COM Toxoplasma gondii}

\author{
Luís Fernando Santana ${ }^{1}$ \\ Roberta Cordeiro Gaspar² \\ Gabriel Augusto Marques Rossi2 ${ }^{*}$ \\ Gabriel Antônio Nogueira Nascentes ${ }^{1}$ \\ Eliana Aparecida Rodrigues ${ }^{1}$ \\ Gilson Pereira de Oliveira ${ }^{3}$ \\ Alvimar José da Costa ${ }^{3}$
}

\begin{abstract}
${ }^{1}$ Instituto Federal de Educação, Ciência e Tecnologia do Triângulo Mineiro, Uberaba, Minas Gerais, Brazil 2Universidade Estadual Paulista, Faculdade de Ciências Agrárias e Veterinárias (FCAV), Departamento de Medicina Veterinária Preventiva e Reprodução Animal, Jaboticabal, São Paulo, Brazil

3Universidade Estadual Paulista, Faculdade de Ciências Agrárias e Veterinárias (FCAV), Centro de Pesquisas em Sanidade Animal (CPPAR), Jaboticabal, São Paulo, Brazil.

*Autor para correspondência - gabrielrossiveterinario@hotmail.com
\end{abstract}

\begin{abstract}
:
Toxoplasmosis is a parasitic disease that affects reproductive performance in small ruminants. Although the Toxoplasma gondii life cycle is well understood since 1960s, several aspects related to its infection remains unclear. This study aimed to determine the effects of $T$. gondii experimental infection, and the influence on clinical, hematological, parasitemia and seminal parameters in male goats. Nine animals were selected and distributed in three groups: GI $(n=3)-$ control group (placebo) orally inoculated with saline solution; GII $(n=3)$ - subcutaneously inoculated with 1 x $10^{6}$ tachyzoites of $T$. gondii; and GIII ( $\mathrm{n}=3)$ - orally inoculated with $2 \times 10^{5}$ oocysts of $T$. gondii. After that, clinical exams, serological tests, hemograms, parasitemia determination and semen evaluation were performed. Reciprocal serological titers had highest values of 4096 in both groups of goats infected with $T$. gondii, confirming the experimental infections. However, we could not observe clinical changes (except for mild hyperthermia on the $5^{\text {th }}$ DAI in one of the animals - GIII) or in hematimetric parameters. Although there were some statistically significant changes $(\mathrm{P}<0.05)$ on the percentages of pathology and sperm concentrations in some of the dates between the infected and control animals, these changes were not associated with toxoplasmic infection. Infection was associated with animal handling methods and environmental factors.
\end{abstract}

Keywords: experimental infection; IFI; reproductive diseases; small ruminant; toxoplasmosis. 


\section{Resumo:}

A toxoplasmose é uma enfermidade parasitária que afeta o desempenho reprodutivo de pequenos ruminantes. Apesar de o ciclo de vida do Toxoplasma gondii ser bem conhecido desde 1960, alguns aspectos relacionados com a infecção permanecem obscuros. Este estudo objetivou determinar os efeitos da infecção experimental por $T$. gondii e a influência sobre parâmetros clínicos, hematológicos, parasitêmicos e seminais de machos da espécie caprina. Nove animais foram selecionados e distribuídos em três grupos: GI $(n=3)$ - grupo controle (placebo) oralmente inoculados com solução salina; GII ( $\mathrm{n}=3$ ) - subcutaneamente inoculados com 1 x $10^{6}$ taquizoítos de T. gondii; e GIII ( $\mathrm{n}=3)$ - oralmente inoculados com $2 \times 10^{5}$ oocistos de T. gondii. Posteriormente, foram realizados exames clínicos, testes sorológicos, hemogramas, determinação de parasitemia e avaliação seminal. Em ambos os grupos infectados com o parasita, a maior titulação sorológica observada foi 4096, confirmando a ocorrência da infecção. Entretanto, não foram observadas alterações clínicas (exceto por hipertermia no $5^{\circ}$ DPI em um dos animais - GIII) ou nos parâmetros hematológicos. Apesar de ocorrer diferença estatística significativa $(P<0,05)$ na porcentagem de patologias e concentração espermática em algumas datas entre os animais controle e infectados, essas alterações não foram associadas ao parasitismo, mas a fatores ambientais e de manejo dos animais.

Palavras-chave: enfermidades reprodutivas; infecção experimental; pequenos ruminantes; RIFI; toxoplasmose.

Recebido em: 17 setembro 2013

Aceito em: 06 maio 2015

\section{Introduction}

Toxoplasma gondii is a protozoa that infects nucleated cells of vertebrate hosts ${ }^{(1)}$, including birds, wild and domestic animals, and also human beings ${ }^{(2)}$. In breeders, such as goats, not only does $T$. gondii lead to fever, but it is also responsible for great economic losses due to abortions, weak newborns, and perinatal mortality ${ }^{(3)}$.

Several studies have shown that the strain of $T$. gondii can be classified into three major genotypically distinct groups, type I (virulent), II and III (non-virulent or low virulence), which can infect animals and humans, and apparently differ in their virulence, biological behavior and epidemiological patterns occurrence. There is a predominance of type II strains in human toxoplasmosis and the most common type III in animals ${ }^{(4,5)}$.

Brazil has a goat herd of over 13 million animals, yet little is known about goat toxoplasmosis. Also, the possibility of human transmission due to goat breeding management activities is worrisome $^{(6)}$. Muday and Mason ${ }^{(7)}$ were the first researchers to describe this disease as a major cause of goat reproductive losses. Besides, although not well documented, the losses seem to be even higher, clinically attacking both young and adult animals ${ }^{(8)}$. According to Cavalcante et al. ${ }^{(9)}$, factors such as the increase in the age of the animals, the number of felines among goat herds, and the types of breeding facilities contribute to increasing the risk of stock contamination. The major route of transmission of toxoplasmosis in goats, as well as in most domestic species, is the ingestion of sporulated oocysts of the parasite ${ }^{(10)}$ found in the environment. 
Information on the seroprevalence of antibodies against $T$. gondii in goats has been reported in many countries, suggesting that this species is an important host ${ }^{(11-13)}$. Serological surveys indicate that stock seropositivity ranges from $28.9 \%$ to $92.4 \%$ in Brazil, showing a high prevalence in that domestic species $^{(11 ; 14-17)}$.

Although there are some studies reporting the occurrence of clinical changes in goats infected with T. gondi $^{(18-20)}$, there was no information found to correlate the effects of toxoplasmic infection in clinical, hematological and seminal parameters in male goats experimentally infected with this parasite, what this study aimed to investigate.

\section{Material and Methods}

The present study was carried out at the Animal Health Research Center $(C P P A R)$ at School of Agrarian and Veterinary Sciences, Universidade Estadual de São Paulo (FCAV/UNESP), Jaboticabal campus, São Paulo, Brazil. Every procedure was approved by the university Animal Ethics and Wellness Committee from UNESP's School of Agriculture and Veterinary in Jaboticabal, São Paulo state, Brazil, under the protocol N. 010850-08.

This study used "P"(21) and "RH"(22) T. gondii strains kept at CPPAR, FCAV/UNESP. "P" strains were genotypically characterized by using PCR-RFLP segment of locus SAG2 located in chromosome VIII as a genetic marker and classified as Type III ${ }^{(23)}$. "RH" strains were previously characterized as Type I by using the same analysis of loci SAG1, SAG2, new SAG2, SAG3, BTUB, GRA6, c22-8, c29-2, L358, PK1 and Apico ${ }^{(24-25)}$.

Nine male goats of undefined breed, serologically negative for T. gondii, aged between one and two years, healthy and in good physical condition, were selected in a specialized rearing facility in the town of Pitangueiras, in the state of São Paulo, Brazil. Serology titers obtained by indirect immunofluorescence (IFI) were considered positive starting at a 1:16 dilution. These nine animals were then kept in proper individual stalls of CPPAR for four weeks prior to the experiment, with water and food at will, with the purpose of letting them adapt to the breeding management conditions and to the facilities.

Serological exams were carried out during the experimental period as follows: acidified buffered antigen test ${ }^{(26)}$ for brucellosis, and microscopic agglutination test ${ }^{(27)}$ for leptospirosis.

The animals were identified, sorted and randomized into three groups with three animals in each, and they were kept isolated until the end of the experiment, as follows: GI (A, B and C) - noninoculated controls; GII (D, E and F) subcutaneously infected with $1 \times 10^{6} \mathrm{RH}$ strain tachyzoites per animal; and GIII (G, H and I) orally infected with $2 \times 10^{5} \mathrm{P}$ strain oocysts per animal.

In order to confirm the real infection arising from inoculum administration: $1 \times 10^{6} \mathrm{RH}$ strain tachyzoites, subcutaneously (GII), and $2 \times 10^{5} \mathrm{P}$ strain oocysts, orally (GIII), blood samples from infected (GII and GIII) and uninfected (GI) goats were collected for serological follow-up using $\mathrm{IFI}^{(28)}$ two days prior to inoculation $\left(-2^{\text {nd }}\right)$, and on days $3^{\text {rd }}, 5^{\text {th }}, 7^{\text {th }}, 11^{\text {th }}, 14^{\text {th }}, 21^{\text {st }}, 28^{\text {th }}, 35^{\text {th }}, 42^{\text {nd }}$, $49^{\text {th }}, 56^{\text {th }}, 63^{\text {rd }}$ and $70^{\text {th }}$ after inoculation (DAI). Serology titers obtained by indirect immunofluorescence (IFI) were considered positive starting at a 1:16 dilution.

With the purpose of following up possible clinical changes arising from experimental infection of the animals, respiratory and cardiac frequency and rectal temperature were taken two days prior to 
inoculum administration $\left(-2^{\text {nd }}\right)$, and on the $3^{\text {rd }}, 5^{\text {th }}, 7^{\text {th }}, 11^{\text {th }}, 14^{\text {th }}, 21^{\text {st }}, 28^{\text {th }}, 35^{\text {th }}, 42^{\text {nd }}, 49^{\text {th }}, 56^{\text {th }}, 63^{\text {rd }}$ and $70^{\text {th }}$ DAI.

Concomitantly with serological and clinical assessment, a laboratory study of each animal was performed using hematological examinations. Therefore, $1 \mathrm{~mL}$ of blood samples was collected by puncturing the jugular vein using 40x12 needles, in consonance with the technique proposed by Rosenfeld $^{(29)}$, and the automated hemograms were performed at Clinical Pathology Laboratory at Veterinary Hospital Governador Laudo Natel at FCAV/UNESP.

Parasitemia was assessed using white mice by inoculation of the leukocytic layer ${ }^{(30)}$ of goats' blood in mice and serology was used to determine if antibodies developed against $T$. gondii. Mouse serum was considered positive for sample that reacted at a diluition of $>64$.

For nearly two months, all animals were submitted to semen collection with an electroejaculator. Ejaculate samples obtained two days before inoculation and on $3^{\text {rd }}, 5^{\text {th }}, 7^{\text {th }}, 11^{\text {th }}$ and $14^{\text {th }}$ DAI and then weekly until the end of the experiment were evaluated for the following sperm parameters: volume, motility, concentration, morphology and vigor ${ }^{(31)}$. Immediately after ejaculation, semen samples were placed in a water bath $\left(38\right.$ to $\left.40^{\circ} \mathrm{C}\right)$ to ensure sperm integrity.

To evaluate sperm motility and vigor, approximately $10 \mu \mathrm{L}$ of semen were used prior to dilution and placed on a slide with a coverslip ${ }^{(31)}$. These exams were conducted in triplicate for each of the samples. The motility data were expressed as a percentage and vigor data, on a scale of 0 to 5 .

For sperm concentration analysis (sperm $/ \mathrm{mL}$ ), in accordance with the methodology described by Chemineau et al. ${ }^{(31)}, 20 \mu \mathrm{L}$ of semen from each goat were diluted in $980 \mu \mathrm{L}$ of saline solution containing $0.1 \%$ formol. The seminal volume was verified by direct observation using a $5 \mathrm{~mL}$ test tube.

For spermatic pathologies evaluation, $50 \mu \mathrm{L}$ semen aliquots were separated from each sample and diluted in $1 \mathrm{~mL}$ of $0.1 \%$ formol saline solution. Next, 200 cells/goat/collection were counted in accordance with the methodology adopted by Chemineau et al. ${ }^{(31)}$.

Pre- and post-inoculation clinic parameters were analyzed as a split-plot in time, taking inoculated and control groups into account. F-test was used for treatment effect and Tukey test was used to compare the treatments.

Seminal parameters were evaluated among the experimental groups (control, infected with tachyzoites and infected with oocystes) using analysis of variance (ANOVA), followed by the Bonferroni's post hoc test for parametric data. In addition, for nonparametric data, we used Kruskal-Wallis test, followed by the post hoc Dunn's test. The statistical analysis were performed using the software Statistica 8.0 (STATSOFT, Tulsa, OK, USA), and p-values of $<0.05$ were taken to be significant.

\section{Results and Discussion}

The serological titers ${ }^{(28)}$ shown in Table 1 confirm the development of toxoplasmic infection with fast immune response from $11^{\text {th }}$ DAI (titer $\geq 1: 64$ ), as reported by Nishi et al. ${ }^{(18)}$ and Santana et al. ${ }^{(32)}$ in similar studies.

We could also observe the highest serological titer was of 1:4096 from $14^{\text {th }}$ to $42^{\text {th }}$ DAI in the group of animals infected with $1.0 \times 10^{6}$ tachyzoites, and on the $21^{\text {st }}$ and $35^{\text {th }}$ DAI in the group of animals infected with $2 \times 10^{5}$ oocysts. Although there were changes in antibody titers of animals 
that received $T$. gondii, throughout the experiment there was a visible decrease in this titer after serological peaks in each inoculated animal. As expected, the animals inoculated with saline showed no growth of $T$. gondii infection throughout the experimental period.

Table 1: Reciprocal titers obtained by indirect immunofluorescence reaction (IFI) in the serum of inoculated goats with $1 \times 10^{6}$ tachyzoites and $2 \times 10^{5}$ oocysts of Toxoplasma gondii.

\begin{tabular}{ccccccc}
\hline \multirow{2}{*}{$\begin{array}{c}\text { Days after } \\
\text { infection } \\
\text { (DAI) }\end{array}$} & \multicolumn{6}{c}{$\begin{array}{c}\text { Reciprocal titers } \\
\text { Inoculated with 1 x 10 } \\
\text { tachyzoites (GII) }\end{array}$} \\
\cline { 2 - 7 } & D & E & F & G & H & I \\
\hline $\mathbf{1 1}$ & 256 & - & 1024 & - & - & 256 \\
$\mathbf{1 4}$ & 4096 & 1024 & 256 & - & 256 & 256 \\
$\mathbf{2 1}$ & 4096 & 4096 & 4096 & - & 4096 & 4096 \\
$\mathbf{2 8}$ & 4096 & 4096 & 4096 & 2048 & 4096 & 4096 \\
$\mathbf{3 5}$ & 1024 & 4096 & 1024 & 4096 & 1024 & 1024 \\
$\mathbf{4 2}$ & 1024 & 4096 & 1024 & 2048 & 1024 & 1024 \\
$\mathbf{4 9}$ & 1024 & 2048 & 1024 & 2048 & 1024 & 1024 \\
$\mathbf{5 6}$ & 1024 & 2048 & 1024 & 1024 & 1024 & 1024 \\
$\mathbf{6 3}$ & 1024 & 2048 & 1024 & 1024 & 1024 & 1024 \\
$\mathbf{7 0}$ & 1024 & 2048 & 1024 & 1024 & 1024 & 1024 \\
\hline
\end{tabular}

According to Dubey et al. ${ }^{(33)}$, the mean rectal temperature of adult goats in normal physiological conditions may reach up to $40.5^{\circ} \mathrm{C}$. In this study, as shown in Figure 1, a mild episode of hyperthermia could be noticed on the $5^{\text {th }}$ DAI in the group of animals inoculated with oocysts (GIII).

Even though there were changes in the mean rectal temperatures in the experimental groups on the course of the experiment, they were within the normality range of the studied species. The hyperthermia episode was similar to the findings of Nishi et al. ${ }^{(18)}$, who reported this change as being one of the most evident clinical signs in goats orally inoculated with $10^{5}$ oocysts of $T$. gondii. Dubey et al. ${ }^{(33)}$, Chhabra et al. $^{(20)}$ and Dubey ${ }^{(19)}$ have also observed similar clinical symptomatologies, as well as the death of an animal inoculated with oocysts ${ }^{(19)}$.

Although there have been changes in cardiac and respiratory frequencies at several dates throughout the experiment, for the groups GI, GII and GIII, these changes were not statistically related to $T$. gondii infection or were within normal ranges for this species ${ }^{(34)}$.

Due to the lack of scientific studies on hematological parameters of males experimentally infected with $T$. gondii, this study aimed to compare the parameters of the experimental animals with the parameters considered to be normal for this domestic species, as well as the parameters collected in the control group and on $-2^{\text {nd }}$ DAI for all experimental groups.

The oscillation in average red blood count could be observed in the three groups throughout the experiment, including in the non-inoculated group (control group). Therefore, experimental infection with $T$. gondii could not be deemed responsible for any change in this parameter. According to Elitok, ${ }^{(37)}$ the reference value for red blood cell count in adult male goats is 
$23.09 \pm 3.63 \times 10^{12} / \mathrm{L}$. Although, it was noticed that on some experiment dates this highest value exceeded, it was not statistically different $(\mathrm{P}>0.05)$ from the other experimental groups.

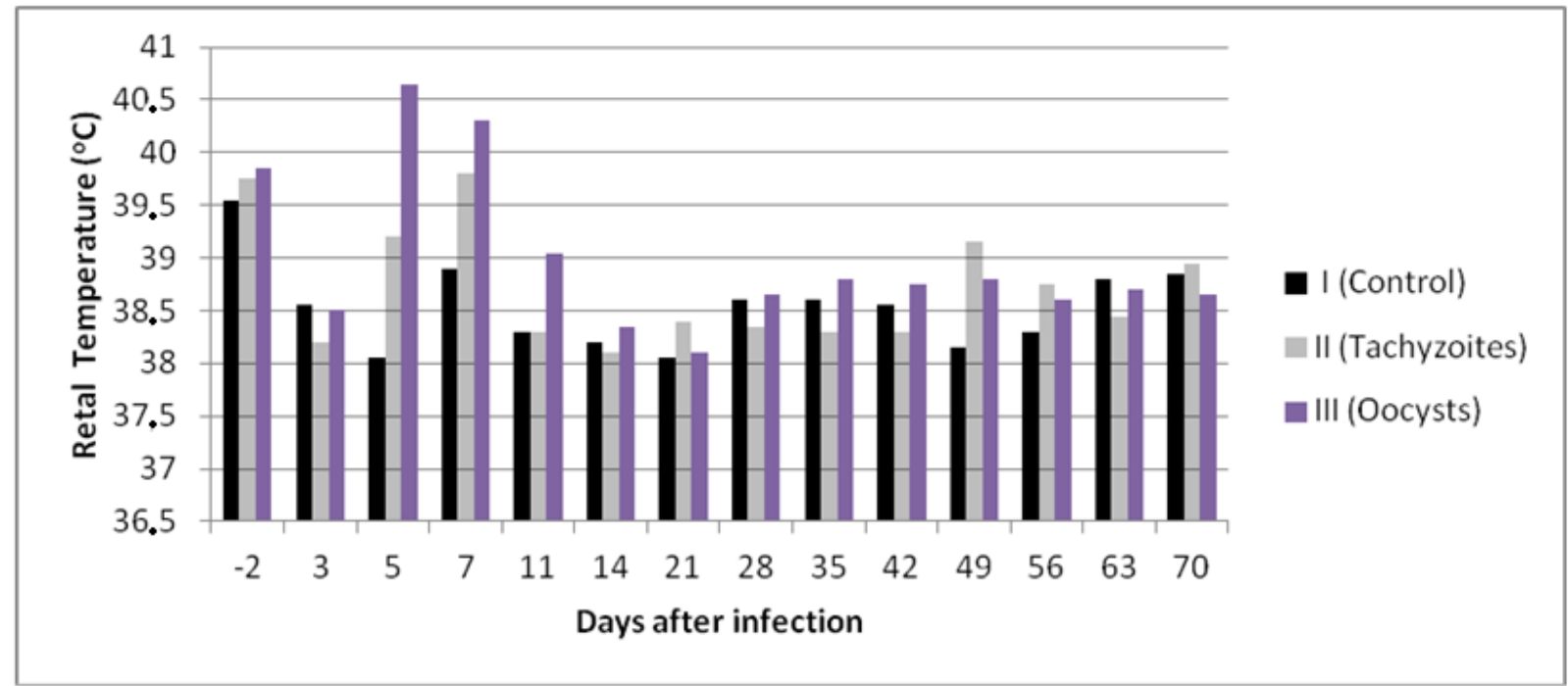

Figure 1: Mean rectal temperature in non-inoculated male goats (GI) and in male goats experimentally inoculated with $1 \times 10^{6}$ tachyzoites (GII) and with $2 \times 10^{5}$ oocysts of Toxoplasma gondii (GIII)

Considering the adopted reference values of hemoglobin concentration, ${ }^{(35)} 13.34 \pm 0.14 \mathrm{~g} / \mathrm{dL}$, in this study, average values of hemoglobin concentration $(\mathrm{g} / \mathrm{dL})$ in groups GII and GIII were similar to those found in group GI (control group) on the same dates throughout the study. There were no statistically significant differences $(\mathrm{P}>0.05)$ among the observed values.

A gradual reduction in the mean values of hematocrit was noticed in the three groups from the $35^{\text {th }}$ DAI to the end of the experiment. Such reduction was also observed in the group of non-inoculated animals with $T$. gondii, which rules out the hypothesis of change due to protozoa infection in the remaining experimental groups. Another extremely relevant datum is that there was no statistically significant difference $(\mathrm{P}>0.05)$ in the mean values of hematocrit $(\%)$ among the groups throughout the experiment on any of the dates. Furthermore, such values were within the normality range $(22 \%-38 \%)$ of the species being studied ${ }^{(35)}$.

Reduction in total value count of leukocytes (x 10\% /UI) in the three groups was observed from the $3^{\text {rd }}$ to the $11^{\text {th }}$ DAI. Nevertheless, besides being within the normality range, $13.84 \pm 0.21 \times 10^{3} / \mathrm{UI}^{(35)}$, these mean values did not have statistically significant differences $(\mathrm{P}>0.05)$ when comparing the groups on the same experiment dates, thus, they cannot be considered episodes of leukopenia.

According to Egbe-Nwiyi et al. ${ }^{(35)}$, the mean values of eosinophil and monocytes count were within the normality limits for this species $(452.2 \pm 56.53$ cells $/ \mu \mathrm{L}$ and $442.0 \pm 88.74$, respectively) throughout the experiment. Moreover, these values did not differ statistically $(\mathrm{P}>0.05)$ among the groups on any date after the infection.

Values of banded neutrophil count in this study were rare, which was also within the normality values for this parameter in goats ${ }^{(35)}$. Normal reference parameters of segmented neutrophil should range from 30 to $48 \%$ of total leukocyte count, that is $5715.9 \pm 165.2 / \mu \mathrm{L}^{(35)}$. In this study, a 
variation in the absolute mean values of the three groups could be noticed, yet, without exceeding the normality limit for this parameter.

Episodes of lymphopenia in animals inoculated with oocysts $\left(3^{\text {rd }} \mathrm{DAI}\right)$ and with tachyzoites $\left(3^{\text {rd }}\right.$ and $42^{\text {nd }}$ DAI) were observed; moreover, lymphocyte count was lower on these dates, being statistically different $(\mathrm{P}<0.05)$ from the values found in animals in the control group . However, in spite of this difference, such values were within the normality range for this parameter in goats, $7203 \pm 264 / \mu \mathrm{L}^{(35)}$. On other experiment dates, such as on the $63^{\text {rd }}$ and $70^{\text {th }}$ DAI, we noticed low mean count of lymphocytes, mainly regarding the animals inoculated with oocysts. Nonetheless, these values were still within the normality range although they did not differ statistically from the means of the other experimental groups $(\mathrm{P}>0.05)$.

Table 2: Spermatic concentration obtained of non-inoculated goats (control group - GI) and of inoculated goats with $1 \times 10^{6}$ tachyzoites (GII) and $2 \times 10^{5}$ oocysts (GIII) of Toxoplasma gondii.

\begin{tabular}{|c|c|c|c|c|}
\hline \multirow[b]{2}{*}{ Days after Infection (DAI) } & \multicolumn{3}{|c|}{ Spermatic concentration (sperm/mL) per group } & \multirow[b]{2}{*}{ Value-p ${ }^{2}$} \\
\hline & $\begin{array}{c}\text { Inoculated with } \\
\text { saline solution (GI } \\
\text { - Control) }\end{array}$ & $\begin{array}{l}\text { Inoculated with } 1 \mathrm{x} \\
10^{6} \text { tachyzoites (GII) }\end{array}$ & $\begin{array}{c}\text { Inoculated with } 2 \times \\
10^{5} \text { oocysts (GIII) }\end{array}$ & \\
\hline Day -2 & $30,7 \pm 12,5$ & $57,3 \pm 16,2$ & $40,0 \pm 4,6$ & 0,088 \\
\hline Day 3 & $36,3 \pm 4,2$ & $50,0 \pm 14,5$ & $39,7 \pm 5,7$ & 0,251 \\
\hline Day 5 & $37,0 \pm 14,2$ & $49,7 \pm 4,6$ & $32,3 \pm 9,6$ & 0,181 \\
\hline Day 7 & $31,3 \pm 9,3 \mathrm{~b}$ & $50,7 \pm 5,5$ a & $44,7 \pm 3,8$ ab & 0,029 \\
\hline Day 11 & $31,3 \pm 4,5$ & $50,3 \pm 15,7$ & $50,7 \pm 2,5$ & 0,077 \\
\hline Day 14 & $44,7 \pm 13,7$ & $56,3 \pm 11,5$ & $43,0 \pm 9,8$ & 0,380 \\
\hline Day 21 & $40,3 \pm 10,1$ & $53,3 \pm 12,2$ & $38,7 \pm 11,7$ & 0,297 \\
\hline Day 28 & $35,0 \pm 13,7$ & $47,7 \pm 13,0$ & $42,0 \pm 10,5$ & 0,503 \\
\hline Day 35 & $39,3 \pm 11,0$ & $47,3 \pm 9,2$ & $42,3 \pm 9,5$ & 0,632 \\
\hline Day 42 & $32,0 \pm 12,0$ & $53,0 \pm 14,7$ & $42,7 \pm 4,7$ & 0,155 \\
\hline Day 49 & $37,7 \pm 0,6 \mathrm{~b}$ & $51,3 \pm 4,0 \mathrm{a}$ & $40,0 \pm 2,6 b$ & 0,002 \\
\hline Day 56 & $29,3 \pm 11,5 b$ & $53,0 \pm 8,5$ a & $30,7 \pm 8,1 \mathrm{~b}$ & 0,039 \\
\hline Day 63 & $36,0 \pm 19,2$ & $47,7 \pm 10,4$ & $40,0 \pm 1,7$ & 0,550 \\
\hline Day 70 & $28,3 \pm 3,1 \mathrm{~b}$ & $46,7 \pm 5,9$ a & $41,3 \pm 5,7 \mathrm{a}$ & 0,011 \\
\hline
\end{tabular}

\footnotetext{
${ }^{1}$ Values are expressed as mean \pm standard deviation
}

${ }^{2}$ The p-value refers to the result of the ANOVA test for independent samples. Days when the ANOVA test showed a significant result $(\mathrm{p}<0.05)$ are marked in bold, different letters indicate significant differences between groups observed after Bonferroni's test for multiple comparisons.

Parasite presence in the blood of the male goats infected with tachyzoites (GII) was verified on $11^{\text {th }}, 14^{\text {th }}, 28^{\text {th }}, 49^{\text {th }}, 56^{\text {th }}, 63^{\text {rd }}$ and $70^{\text {th }}$ DAIs, and on $14^{\text {th }}, 21^{\text {st }}, 56^{\text {th }}, 70^{\text {th }}$ DAIs for the male goats infected with oocysts (GIII). The high frequency of parasitic outbreaks observed in the male goats 
could be related to the susceptibility of the host to $T$. gondii, as also shown by Nishi et al., ${ }^{(18)}$ Chhabra et al. ${ }^{(20)}$ and Dubey et al. ${ }^{(33)}$.

Although statistical differences $(\mathrm{P}<0.05)$ were observed for spermatic concentration and pathologies (Tables 2 and 3, respectively) in the goats throughout the experiment, these could not be directly related to toxoplasmic infection; thus, these could be dependent on other factors, such as the collection technique, semen manipulation and scrotal temperature, among others.

Table 3: Spermatic pathologies obtained of non-inoculated goats (control group - GI) and of inoculated goats with $1 \times 10^{6}$ tachyzoites (GII) and $2 \times 10^{5}$ oocysts (GIII) of Toxoplasma gondii.

\begin{tabular}{|c|c|c|c|c|}
\hline \multirow[b]{2}{*}{$\begin{array}{c}\text { Days after } \\
\text { Infection (DAI) }\end{array}$} & \multicolumn{3}{|c|}{ Spermatic pathologies ( $\%$ ) per group } & \multirow[b]{2}{*}{ Value-p } \\
\hline & $\begin{array}{c}\text { Inoculated with saline } \\
\text { solutino (GI - } \\
\text { Control) }\end{array}$ & $\begin{array}{c}\text { Inoculated with } 1 \times 10^{6} \\
\text { tachyzoites (GII) }\end{array}$ & $\begin{array}{l}\text { Inoculated with } 2 \mathrm{x} \\
10^{5} \text { oocysts (GIII) }\end{array}$ & \\
\hline Day -2 & $1,3 \pm 0,6$ & $4,7 \pm 1,2$ & $5,3 \pm 1,5$ & 0,054 \\
\hline Day 3 & $1,0 \pm 0,0$ & $2,0 \pm 1,0$ & $1,0 \pm 1,0$ & 0,294 \\
\hline Day 5 & $4,7 \pm 1,2$ & $4,3 \pm 0,6$ & $2,7 \pm 1,2$ & 0,136 \\
\hline Day 7 & $3,0 \pm 1,0$ & $6,0 \pm 1,0$ & $3,3 \pm 0,6$ & 0,057 \\
\hline Day 11 & $3,7 \pm 0,6$ & $2,0 \pm 1,0$ & $2,0 \pm 1,0$ & 0,104 \\
\hline Day 14 & $1,7 \pm 0,6$ & $1,3 \pm 1,5$ & $1,7 \pm 0,6$ & 0,860 \\
\hline Day 21 & $2,0 \pm 0,0 \mathrm{ab}$ & $1,3 \pm 0,6 b$ & $3,7 \pm 0,6 \mathrm{a}$ & $\mathbf{0 , 0 3 2}$ \\
\hline Day 28 & $1,3 \pm 0,6 b$ & $2,0 \pm 1,0 a b$ & $4,7 \pm 1,2 \mathrm{a}$ & 0,048 \\
\hline Day 35 & $5,7 \pm 3,8$ & $4,3 \pm 3,2$ & $6,3 \pm 2,1$ & 0,553 \\
\hline Day 42 & $2,0 \pm 1,0$ & $3,3 \pm 0,6$ & $5,0 \pm 1,7$ & 0,088 \\
\hline Day 49 & $3,3 \pm 0,6$ & $4,0 \pm 1,0$ & $4,0 \pm 2,0$ & 0,717 \\
\hline Day 56 & $0,3 \pm 0,6 b$ & $2,0 \pm 1,0 \mathrm{ab}$ & $5,3 \pm 1,5 \mathrm{a}$ & 0,031 \\
\hline Day 63 & $1,7 \pm 0,6$ & $2,0 \pm 1,7$ & $4,3 \pm 0,6$ & 0,100 \\
\hline Day 70 & $4,3 \pm 1,5$ & $4,7 \pm 1,2$ & $5,3 \pm 2,1$ & 0,741 \\
\hline
\end{tabular}

${ }^{1}$ Values are expressed as mean \pm standard deviation.

${ }^{2}$ The p-value refers to the result of the Kruskal-Wallis test for independent samples. Days when the KruskalWallis test showed a significant result $(\mathrm{p}<0.05)$ are marked in bold, different letters indicate significant differences between groups observed after Dunn's test for multiple comparisons.

Moura et al. ${ }^{(36)}$ affirmed that a direct effect of $T$. gondii on spermatogenesis should be accompanied by a significant increase in the frequency of primary pathologies, as well as relevant alterations in semen variables. However, some factors like temperature were difficult to control and could influence these results. No significant differences $(\mathrm{P}>0.05)$ were observed between the control and infected animals concerning motility, vigor and volume obtained. 


\section{Conclusion}

Despite having found hyperthermia in the group of animals inoculated with Toxoplasma gondii oocysts just on one experimental date, the infection was asymptomatic, without clinical or hematological changes in the inoculated goats. Thus, recognition and posterior treatment of animals infected by this parasite is hindered. Furthermore, despite the absence of changes in the evaluated clinical parameters, attention should be paid to this parasitosis, not only because of the economic losses it leads to but also because of its relevance to public health.

\section{Acknowledgements}

The present study was funded by São Paulo Research Foundation (FAPESP) under processes 04/12296-2 and 08/11290-1, and by Animal Health Research Center (CPPAR) at UNESP's School of Agriculture and Veterinary in Jaboticabal, in the São Paulo State, Brazil.

\section{References}

1. Hoff EF, Carruthers B. Is Toxoplasma aggress the first step in invasion? Trends Parasitol, 2002;18(6):251255.

2. Tenter AM, Heckeroth AR, Weiss LM. Toxoplasma gondii: from animals to humans. Int. J. Parasitology, 2000 Nov;30(12-13):1217-58.

3. Dubey JP, Adams DS. Prevalence of Toxoplasma gondii antibodies in dary goat from 1982 to 198. J.Am Vet Med Assoc, 1990;(196):295-296.

4. Diana J, Persat F, Staquet MJ, Assossou O, Ferrandiz J, Gariazzo MJ, Peyron F, Picot S, Schmitt D, Vincent C. Migration and maturation of human dendritic cells infected with Toxoplasma gondii depend on parasite strain type. FEMS Immun Med Microb , 2004; 42(3):321-331.

5. Villena I, Marle M, Darde ML, Pinon Jm, Aubert D. Toxoplasma strain type and human disease: risk of bias during parasite isolation? Trends Parasitol. 2004;20(4):160-162.

6. Ishag MY, Majud AM. Toxoplasma gondii Infection among a caprine farm workers. Int J Trop Med, 2008;3(1):12-14.

7. Munday BL, Mason RW. Toxoplasmosis as a cause of perinatal death in goats. Austr. Vet J, 1979;55(10):485-487.

8. Dubey JP. Toxoplasmosis in goats. Agri-practice, 1987;8(3):43-52.

9. Cavalcante ACR, Carneiro M, Gouveia AMG, Pinheiro RR, Vitor RWA. Risk factor for infection by Toxoplasma gondii in heards of goats in Ceará, Brazil. Arq Bras Med Vet e Zoot, 2008;60(1):36-41.

10. Tenter AM, Heckeroth AR, Weiss LM. Toxoplasma gondii: from animals to humans. Int. J. Parasitol, 2000;30(12-13):1217-1258.

11. Machado TMM, Lima JD. Freqüência de anticorpos anti-Toxoplasma gondii em caprinos criados sob diferentes formas de exploração no Estado de Minas Gerais. Arq Bras Med Vet Zoot, 1987;39(2):255-264. 
12. Kamani J, Mani AU, Egwu GO. Seroprevalence of Toxoplasma gondii infection in domestic sheep and goats in Borno state, Nigeria. Trop Anim Health Product, 2010;42(4):793-797.

13. Gebremedhin EZ, Gizaw D. Seroprevalence of Toxoplasma gondii infection in sheep and goats in the districts of southern nations, nationalities and peoples' region of Ethiopia. World Appl Sci J, 2014; 31(11):1891-1896.

14. Chiari CA, Neves DP. Toxoplasmose humana adquirida através da ingestão de leite de cabra. Mem Instit Oswaldo Cruz, 1984;79(3):337-340.

15. Sella MZ, Navarro IT, Vidotto O, Freire RL, Shida PN. Toxoplasmose caprina: levantamento sorológico do Toxoplasma gondii em caprinos leiteiros na microregião de Londrina, Paraná, Brasil., Rev Bras Parasitol Vet, 1994;3(13):13-16.

16. Mainardi RS, Modolo JR, Stachissini AVM, Padovani CR, Langoni H. Soroprevalência de Toxoplasma gondii em rebanhos caprinos no Estado de São Paulo. Rev Soc Bras Med Trop, 2003;36:759-761.

17. Medeiros AD, Andrade MMC, Vitor RWA, Andrade-Neto VF. Occurrence of anti-Toxoplasma gondii antibodies in meat and dairy goat herds in Rio Grande do Norte, Brazil. Rev Bras Parasitol Vet, 2014; 23(4):481-487.

18. Nishi SM, Kasai N, Gennari SM. Antibody levels in goats fed Toxoplasma gondii oocysts. J. Parasitol. 2001,87:447-452.

19. Dubey, JP. Lesions in goats fed Toxoplasma gondii oocysts, Vet Parasitol, 1989;32(2-3):133-144.

20. Chhabra MB, Mahajan SK, Gupta SL. Experimental toxoplasmosis in pregnant goats. Ind J Anim Sci, 1982;52:661-664.

21. Jamra LMF, Vieira MPL. Isolamento do Toxoplasma gondii de exsudato peritoneal e órgãos de camundongos com infecção experimental. Rev Instit Med Trop São Paulo, 1991; (33):435-441.

22. Sabin AB. Toxoplasmic encephalitis in children. J Amer Med Assoc, 1941;116(9):801-807.

23. Bresciani KDS, Costa AJ, Toniollo G, Luvizotto MCR, Kanamura C, Moraes FR, Perri SHV, Gennari SM. Transplacental transmission of Toxoplasma gondii in reinfected pregnant female canines. Parasitol Res, 2009;104(5):1213-1217.

24. Pena HFJ, Gennari SM, Dubey JP, Su C. Population structure and mouse-virulence of Toxoplasma gondii in Brazil. Int J Parasitol, 2008;38(5):561-569.

25. Herrmann DC, Pantchev N, Globokar Vrhovec M, Barutzki D, Wilking H, Frohlich A, Luder CGK, Contraths FJ, Schares G. Atypical Toxoplasma gondii genotypes identified in oocysts shed by cats in Germany. Int J Parasitol 2010; 40(3):285-292.

26. Alton GG, Jones LM, Angus RD, Verger JM. Techniques for the brucellosis laboratory. Institut National de la Recherche Agronomique, 1988, p.190.

27. Cole JR, Sulzer CR, Pulssely PR. Improved microtechinique for the leptospiral microscopic agglutination. Appl Microb, 1973;25(6):976-980.

28. Camargo ME. Improved technique of indirect immunofluorescence for serological diagnosis of toxoplasmosis. Rev Instit Med Trop, 1964;6(3):117-118.

29. Rosenfeld G. Etileno diamina Tetracética Disódica (EDTA) como anticoagulante para técnica hematológica. Vet Clinic, 1995;31:65-71, 1995. 
30. Oliveira FCR, Costa AJ, Bechara GH, Sabatini GA. Distribuição e viabilidade de cistos de Toxoplasma gondii (Apicomplexa: Toxoplasmatinae) em tecidos de Bos indicus, Bos taurus and Bubalus bubalis infectados com oocistos. Rev Bras Med Vet, 2001;23(1):28-34.

31. Chemineau P, Cagnié Y, Guérin Y, Orgeur P, Vallet JC. Training manual on artificial insemination in sheep and goats. Food and Agriculture Organization of the United Nations (FAO). FAO Animal Production and Health Paper. p. 211-222, 1991.

32. Santana LF, Costa AJ, Pieroni J, Lopes WDZ, Santos RS, Oliveira GP, Mendonça RP, Sakamoto CAM. Detecion of Toxoplasma gondii in the reproductive system of male goats. Rev Bras Parasitol Vet, 2010; 19(3):179-182.

33. Dubey JP, Sharma SP, Lopes CW, Williams JF, Willians CS, Weisbrode SE Caprine toxoplasmosis: abortion, clinical signs, and a distribution of Toxoplasma in tissues of goats fed Toxoplasma gondii oocysts. Am J Vet Res, 1980;41(7):1072-1076.

34. Smith JL. Documented outbreaks of toxoplasmosis: Transmission of Toxoplasma gondii to humans. J Food Protec, 1993;56(7):630-633.

35. Egbe-Nwiyi TN, Nwaosu SC, And Salami HA. Haematological values of appararently healthy sheep and goats as influenced by age and sex in arid zone of Nigeria. Afr. J. Biomed. Res, 2000;3(2): 109-115.

36. Moura AB, Jordão-Filho S, Mauro DC, Paim BB, Pinto FR, Costa AJ. Avaliação dos parâmetros seminais de cachaços (Sus scrofa) experimentalmente infectados com Toxoplasma gondii.. Semina; Ciênc Agrar, 2003; 25(2):107-116.

37. Elitok B. Reference values for hematological and biochemical parameters in Saanen goats breeding in Afyonkarahisar province. Kocatepe Vet. J, 2012;5(1): 7-11. 